\title{
The 2013 Elliott Youth Development Lecture
}

\author{
Roger J. R. Levesque
}

Received: 6 January 2015/Accepted: 8 January 2015/Published online: 13 January 2015

(C) Springer Science+Business Media New York 2015

I am most pleased to introduce the 2013 Elliott Youth Development Lecture. The lecture is authored and presented by a leading researcher widely recognized as having made foundational contributions to our understanding of youth. In 2013, Ronald L. Simons was selected as the recipient of this recognition by a group of researchers at Indiana University, where the lecture was delivered. His engaging presentation became the basis of the invited article published in this issue. We extend our appreciation to Mark T. Berg, a former faculty member at Indiana University, for inviting Professor Simons and serving as host.

The lecture is supported by a generous donation from Howard R. "Skip" Elliott, BA'77. Elliott was a double major in Forensic Studies and English and continues to be a faithful alumnus of what has become known as the Department of Criminal Justice at Indiana University. After graduating from the Department, Elliott then graduated from the state police academy, after which he joined the police department of Conrail railroad. Eventually, he joined CSX Transportation, where he currently serves as vice president of public safety and environment. CSX Transportation is one of America's major freight railroads and a Fortune 250 Company that operates in 23 states and in cities such as Chicago, Boston, and New York City. Elliott leads CSX's hazardous materials transportation safety efforts, its environmental protection program, its police department and its homeland security initiatives. Among his many commitments to public service is his exemplary service to National Safe Place, an organization that links runaway and homeless youth with the help needed to be safe (see Walsh and Donaldson 2009). Elliott

R. J. R. Levesque ( $\square)$

Indiana University, 302 Sycamore Hall, Bloomington, IN, USA

e-mail: rlevesqu@indiana.edu earned Indiana University's Department of Criminal Justice's first-ever Distinguished Alumni Award, for the great credit he has given the Department, Indiana University, and the field of criminal justice. It was Elliott's dedication to serving others, and his passion for helping youth, that led to the development of this lecture series.

The Elliott Youth Development Lecture has many goals. The lecture seeks to recognize the accomplishments of a leading scholar who has made a foundational impact on our understanding of youth and social responses to them. It does so by requesting that the lecturers offer a review of their work, their sense of where the field is heading, and their thoughts on potentially fruitful research and policy directions. Publishing a written version of the lecture helps to enhance its reach and, equally importantly, attract increased attention to the multidisciplinary study of adolescence.

Professor Simons was the ideal recipient of this honor. $\mathrm{He}$ currently is a distinguished research professor in the Department of Sociology and a fellow in the Institute for Behavior Research at the University of Georgia. Dr. Simons also is a Senior Fellow in the Owens Institute for Behavioral Research and Affiliate in both the Center for Gene-Social Environment Transaction and the Center for Contextual Genetics and Prevention Science at the University of Georgia. He received his doctorate from Florida State University and completed his postdoctoral work at the University of Wisconsin. Using a life course perspective, he has investigated a wide variety of issues relating to child and adolescent development. Over the years, his articles have examined the manner in which family processes, peer associations, community contexts, and incarceration combine to influence risk for criminal behavior and emotional problems; the effect of discrimination and racial socialization on physical and mental health; social experiences and cognitive schemas that influence the 
quality of romantic relationships; and, most recently, ways in which gene expression and biomarkers of inflammation mediate the impact of the social environment on physical and mental health.

Dr. Simons has served as principal or co-principle investigator on multiple longitudinal studies, including the Iowa Youth and Families Project (IYFP) during the 1990s and the Family and Community Health Study (FACHS) in the new millennium. His work has been generously supported by the various National Institutes of Health. This includes major grants from the National Institute of Mental Health, the National Institute of Child Health and Human Development, the National Institute of Drug Abuse, and the National Heart, Lung, Blood Institute. This research is truly interdisciplinary as his scientific team includes medical and family sociologists, social and clinical psychologists, a geneticist, and a psychiatrist.

Dr. Simons is author or co-author of roughly 200 peerreviewed articles, three books, and numerous chapters. With over 17,000 citations, his work is widely cited by researchers in the fields of criminology, psychology, sociology, family science, and public health. He has received several awards for his research. For example, three different organizations have given him the best article of the year award: the National Conference of Family Relations in 2002, the American Academy of Criminal Justice in 2006, and the American Society of Criminology in 2013.

Dr. Simons' lecture was the third in our series (see Levesque 2011, 2013). Not surprisingly, his research has been featured many times in our journal, with recent research ranging from a focus on corporal punishment (Evans et al. 2012; Simons et al. 2012), religiosity (Landor et al. 2011), and romantic relationships (Kogan et al. 2013) to interparental aggression (Su et al. 2011) and teen parenting (Barr et al. 2013). Currently, his research is concerned with the manner in which social experiences, especially during childhood and adolescence, become biologically embedded and influence mental and physical health. Consonant with this new focus, his lecture and subsequent article with Eric Klopack, describe the paradigmatic shifts that have taken place in genetics and neuroscience and the exciting opportunities that this presents for developmental scientists. This line of inquiry is an important one for our field, as well as our journal. Recently, the journal has showcased research examining genetic and physiological influences on adolescents' health (Wickrama et al. 2014), delinquency risk (Newsome and Sullivan 2014), and depressive symptoms (Morgan et al. 2013; Marceau et al. 2012) as well as the environmental effects on adolescents' physiological development (Brenner et al. 2013). Given the high level of interest in integrating different dimensions of adolescent development, coupled with methods and data permitting that integration, one cannot help but be amazed at the field's development, and Ron Simons' place in it.

\section{References}

Barr, A. B., Simons, R. L., Simons, L. G., Gibbons, F. X., \& Gerrard, M. (2013). Teen motherhood and pregnancy prototypes: The role of social context in changing young African American mothers' risk images and contraceptive expectations. Journal of Youth and Adolescence, 42, 1884-1897.

Brenner, A. B., Zimmerman, M. A., Bauermeister, J. A., \& Caldwell, C. H. (2013). The physiological expression of living in disadvantaged neighborhoods for youth. Journal of Youth and Adolescence, 42, 792-806.

Evans, S. Z., Simons, G. L., \& Simons, R. L. (2012). The effect of corporal punishment and verbal abuse on delinquency: Mediating mechanisms. Journal of Youth and Adolescence, 41, 1095-1110.

Kogan, S. M., Lei, M.-K., Grange, C. R., Simons, R. L., Brody, G. H., Gibbons, F. X., \& Chen, Y.-F. (2013). The contribution of community and family contexts to African American young adults' romantic relationship health: A prospective analysis. Journal of Youth and Adolescence, 42, 878-890.

Landor, A., Simons, L. G., Simons, R. L., Brody, G. H., \& Gibbons, F. X. (2011). The role of religiosity in the relationship between parents, peers, and adolescent risky sexual behavior. Journal of Youth and Adolescence, 40, 296-309.

Levesque, R. J. R. (2011). The Elliott youth development lecture. Journal of Youth and Adolescence, 40, 759-760.

Levesque, R. J. R. (2013). The 2012 Elliott youth development lecture. Journal of Youth and Adolescence, 42, 1637-1639.

Marceau, K., Neiderhiser, J. M., Lichtenstein, P., \& Reiss, D. (2012). Genetic and environmental influences on the association between pubertal maturation and internalizing symptoms. Journal of Youth and Adolescence, 41, 1111-1126.

Morgan, J. K., Shaw, D. S., \& Forbes, E. E. (2013). Physiological and behavioral engagement in social contexts as predictors of adolescent depressive symptoms. Journal of Youth and Adolescence, 42, 1117-1127.

Newsome, J., \& Sullivan, C. J. (2014). Resilience and vulnerability in adolescents: Genetic influences on differential response to risk for delinquency. Journal of Youth and Adolescence, 43, 1080-1095.

Simons, G. L., Simons, R. L., \& Su, Z. (2012). Consequences of corporal punishment among African Americans: The importance of context and outcome. Journal of Youth and Adolescence, 41, $1273-1285$.

Su, X., Simons, R. L., \& Simons, L. G. (2011). Interparental aggression and antisocial behavior among African American youth: A simultaneous test of competing explanations. Journal of Youth and Adolescence, 40, 1489-1502.

Walsh, S. M., \& Donaldson, R. E. (2009). Invited commentary: National safe place: Meeting the immediate needs of runaway and homeless youth. Journal of Youth and Adolescence, 39, 437-445.

Wickrama, K. A. S., O’Neal, C. W., \& Oshri, A. (2014). Are stressful developmental processes of youths leading to health problems amplified by genetic polymorphisms? The case of body mass index. Journal of Youth and Adolescence, 43, 1096-1109.

Roger J. R. Levesque is Professor of Criminal Justice, Indiana University. He serves as Editor-in-Chief of the Journal of Youth and Adolescence and the Adolescent Research Review. 